М.В. Пікуль, Е.О. Стаховський, О.А. Войленко, О.Е. Стаховський, Ю.В. Вітрук, О.А. Кононенко, С.Л. Семко, Б.О. Гречко, Д.О. Кошель, О.О. Каркич

\title{
Клінічна ефективність резекції сечоводу при інвазивних карциномах верхніх сечовивідних
} шляхів

\author{
Національний інститут раку, Київ \\ Одержано 15.09.2021 \\ Прийнято до друку 20.09.2021 \\ DOI: 10.32471/clinicaloncology.2663-466X.41-1.28027
}

Вступ. Враховуючи особливості перебігу карцином верхніх сечовивідних шляхів та частий дебют захворювання з наявною нирковою недостатністю, збереження рівня клубочкової фільтрації є вкрай важливим. Ризик рецидиву захворювання більшою мірою залежить від агресивності самої пухлини, а не від обраного типу втручання. Відповідно, пацієнти з більш агресивними пухлинами частіше будуть потребувати наступної системної терапії, проведення якої часто лімітоване рівнем клубочкової фільтрації після радикальної нефруретеректомії. Матеріали та методи. Враховуючи мету та завдання наукової роботи, пацієнтів було розділено на 2 групи: з карциномою сечоводу, що підлягали органозберігаючому лікуванню (основна група) та радикальній нефруретеректомії (контрольна група). Первинними цілями такого аналізу вважалися оцінка профілю безпеки обох видів хірургічних підходів, що включали визначення тривалості оперативного втручання, інтраопераційну крововтрату, рівень післяопераційних ускладнень за оціночною системою Clavien - Dindo, тривалість післяопераційного стаціонарного лікування. Вторинними цілями дослідження були оцінка віддалених функціональних результатів (загальна клубочкова фільтрація, рівень сироваткового креатиніну через 3 міс після оперативного втручання) та онкологічних результатів (рівні безрецидивної, безпрогресивної, канцер-специфічної та загальної виживаності) обох груп. Результати. При статистично співставних показниках загальної клубочкової фільтрації до оперативного втручання $(p=0,09)$ в післяопераційний період отримано кращі показники в групі резекції сечоводу $(p=0,002)$. Варто відмітити, що такого показника було досягнуто, найбільш вірогідно, за рахунок збереженої нирки на боці ураження (19,3 + 4,9 мл/хв). Відтак органозберігаюче лікування дозволяло утримати загальну клубочкову фільтрацію вище 60 мл/хв, що принципово впливало на вірогідність проведення ефективної системної терапії в післяопераційний період. Важливим моментом є також позитивний вплив такого рівня функції нирок на зниження вірогідності настання кардіоваскулярних подій. Групи були ідентичними за кількістю рецидивів у сечовому тракті. Після радикальної нефроектомії у $31 \%$ випадків спостерігалися імплантаційні ураження сечового міхура, тоді як після резекції сечоводу показник відповідав $25 \%$ (рецидиви в ураженому сечоводі та сечовому міхурі). Таким чином, органозберігаюче лікування статистично достовірно не підвищувало ризик рецидиву в сечовивідній системі (log-rank test; p=0,55). Під час аналізу показників загальної дворічної виживаності також не було відмічено статистичної різниці між хірургічними групами (log-rank test; $p=0,62$ ). Висновки. Резекція сечоводу при уротеліальних карциномах верхніх сечовивідних шляхів високого ризику є безпечним оперативним втручанням з точки зору периопераційних ускладнень у порівнянні з радикальною нефректомією. Органозберігаюче лікування у цих пацієнтів достовірно призводить до збереження функції нирки на боці ураження та рівня загальної клубочкової фільтрації вище 60 мл/хв. Рівень локального контролю в сечовій системі $\epsilon$ співставним при обох хірургічних підходах, що не погіршує кінцевий онкологічний результат.

Ключові слова: уротеліальний рак; карцинома верхніх сечовивідних шляхів; радикальна нефруретеректомія; малоінвазивні органозберігаючі оперативні втручання; клубочкова фільтрація; карцинома сечоводу; хіміотерапія на основі платини

\section{ВстУП}

Резекція сечоводу довела свою ефективність при локалізації новоутворення в нижній його третині, зі збереженням функції нирки та забезпеченням хорошого локального контролю [1]. Перевагами цієї анатомічної зони є технічна простота видалення пухлини, навіть за умови місцево-поширеного процесу, презервація довжини сечоводу та можливість проведення декількох варіантів реконструкції сечовивідних шляхів (прямий анастомоз із сечовим міхуром, пластика за Політано - Лідбеттером, інтрауретеральна пластика за Стаховським та ін). Також важливим онкологічним нюансом є видалення частини сечоводу нижче новоутворення, що попереджує розвиток рецидиву за умови поширення ракових клітин з током сечі (згідно з класичною flow-seeding theory) [2].

Локалізація новоутворення вище рівня нижньої третини $є$ анатомічно більш складною та за умови великої протяжності пухлинного ураження, відновлення прохідності верхніх сечовивідних шляхів за рахунок власних тканин, як правило $є$ неможливим чи створює виражений діастаз тканин, що погіршує ранні та віддалені функціональні результати оперативного втручання [3]. У цьому контексті важливо відмітити, що для проведення такої операції хірург повинен володіти певним арсеналом варіантів пластичного відновлення прохідності сечоводу (у тому числі кишковою пластикою сечоводу). До методів реконструкції верхніх сечовивідних шляхів власними тканинами відносять:

- пластику кінець-в-кінець (при локалізації новоутворення в середній чи верхній третині сечоводу);

- пластику мисково-сечовідного сегмента (про локалізації пухлини в верхній третині сечоводу чи пієло-уретральному відділі);

- пластику сечоводу за допомогою тканин сечового міхура psoas-hitch (при високій локалізації новоутворення в нижній третині чи середній третині сечоводу) чи Боарі (котра не набула широкого використання через незадовільні функціональні результати).

Обмеження цих методик в основному полягає у необхідності максимального збереження власне тканин сечоводу для зменшення складності реконструкції та у разі протяжних резекцій уникнення ймовірної неспроможності накладення анастомозу 3 іншим кінцем сечоводу чи сечовим міхуром. Так, недоліками такого втручання може бути наявність позитивного краю, що може слугувати тригером рецидиву. Відтак вкрай важливою є периопераційна уретероскопія (у тому числі інтраопераційна) та патоморфологічна оцінка країв резекції, що спрямовані на уточнення меж видалення сечоводу [4]. Важливим елементом такої реконструкції 
також слугує попередження діастазу, що може слугувати причиною порушення кровообігу в термінальних відділах анастомозу та, відповідно, розвитку стриктури у цій ділянці. Враховуючи той факт, що нирка на боці ураження достатньо часто є скомпрометованою на момент діагностування карциноми, рецидив обструкції верхніх сечовивідних шляхів може слугувати тригером подальшого зниження ефективності фільтраційних процесів та, відповідно, термінальних змін у ній. Такий результат оперативного втручання можна буде вважати незадовільним, оскільки основною перевагою органозберігаючого лікування є саме збереження функції нирки.

У разі коли через високу вірогідність розвитку натягу сечоводу відновлення його прохідності за рахунок власних тканин є технічно неможливим, оптимальним методом реконструкції верхніх сечовивідних шляхів є проведення кишкової пластики сечоводу. Перевагами даної методики є :

- відсутність діастазу в ділянці анастомозу з тонкою кишкою через можливість виділення іiї сегменту необхідної довжини;

- можливість видалення ураженого сегмента сечоводу будь-якої довжини, що забезпечує кращий локальний контроль.

До недоліків методики можна віднести:

- необхідність проведення кишкового етапу під час оперативного втручання, що асоціюється з вищим ризиком післяопераційних ускладнень

- вища ймовірність розвитку міхурово-ниркового рефлюксу

Відтак, використання цієїпластичної методики є оптимальним з точки зору відсутності потреби в максимальному збереженні тканини сечоводу для наступної реконструкції. Це пов’язано з можливістю заміщення видаленого сегмента будь-якої довжини. Враховуючи те, що уротеліальні карциноми верхніх сечовивідних шляхів часто є мультифокальними, це дозволяє видалити сегмент сечоводу максимальної довжини, знизивши вірогідність рецидиву у вказаній ділянці. Пластика є безпечною для сечовідного анастомозу, так якдозволяє уникнути непотрібного натягу та, відповідно, порушення кровообігу в дистальному відділі сечоводу, запобігаючи таким чином розвитку стриктури та рецидивної обструкції.

Недоліками вказаного методу є вища складність безпосередньо оперативного втручання: наявність кишкового етапу асоціюється з вищим ризиком розвитку периопераційних ускладнень та, відповідно, вищою потенційною летальністю. Іншим клінічним обмеженням є вища складність післяопераційного моніторингу. Виконання уретероскопії є фактично неможливим після такої реконструкції та пацієнт потребує більш частих диспансерних візитів [5]. Вкрай важливим є інтраопераційне проведення профілактики міхурово-ниркового рефлюксу за рахунок модифікації кишкового трансплантату (плікація сечоводу) та інтраілеальної пластики за Стаховським. Такого типу модифікації хірургічної техніки дозволяють захистити нирку від подалышого ушкодження та зниження iї функції, що є вкрай важливим у цих пацієнтів.

Загалом слід констатувати, що, враховуючи особливості перебігу карцином верхніх сечовивідних шляхів та частий дебют захворювання з наявною нирковою недостатністю, збереження рівня клубочкової фільтрації є вкрай важливим. Також варто також відмітити, що ризик рецидиву захворювання більшою мірою залежить від агресивності самої пухлини, а не від обраного типу втручання. Відповідно, пацієнти з більш агресивними пухлинами (у тому числі місцево-поширеними варіантами) частіше будуть потребувати наступної системної терапії, проведення якої часто лімітоване рівнем клубочкової фільтрації після радикальної нефруретеректоміі.

\section{МАТЕРІАЛИ ТА МЕТОДИ}

Клінічний матеріал клініки включає 68 випадків новоутворень сечоводів починаючи з 2008 р. Загальна характеристика основних параметрів цієї групи пацієнтів представлена в табл. 1.

Як видно з табл. 1, усі пацієнти належали до групи високого ризику та згідно з рекомендаціями щодо терапії, що існують на сьогодні, не могли підлягати елективному органозберігаючому лікуванню. Враховуючи гістологічні дані, у всіх хворих відмічали високі ризики рецидиву захворювання та подальшого прогре- сування. 3 даних табл. 1 абсолютно зрозуміло, що досягнення оптимальних онкологічних показників можливе лише за умови проведення периопераційної хіміотерапіі. На користь цього свідчить і високий відсоток уретерогідронефрозів, що є незалежним предиктором більш пізньої стадії захворювання.

Враховуючи мету та завдання наукової роботи, пацієнтів у подальшому було розділено на 2 групи: хворі з карциномами сечоводу, що підлягали органозберігаючому лікуванню (основна група) та радикальній нефруретеректомії (контрольна група). Первинними цілями такого аналізу вважалися оцінка профілю безпеки обох видів хірургічних підходів, що включали визначення тривалості оперативного втручання, інтраопераційну крововтрату, рівень післяопераційних ускладнень за оціночною системою Clavien - Dindo, тривалість післяопераційного стаціонарного лікування. Вторинними цілями дослідження були оцінка віддалених функціональних результатів (загальна клубочкова фільтрація, рівень сироваткового креатиніну через 3 міс після оперативного втручання) та онкологічних результатів (рівні безрецидивної, безпрогресивної, канцер-специфічної та загальної виживаності) обох груп.

Показаннями до проведення органозберігаючого лікування резекції сечоводу з наступною реконструкцією верхніх сечовивідних шляхів були:

1) гістологічно чи цитологічно верифікований діагноз уротеліальної карциноми сечоводу;

2) задовільний соматичний статус пацієнта (ЕСOG 0-1; Karnofsky $->80 \%$ );

3) збережена функція нирки на (>10 мл/хв) згідно з даними динамічної реносцинтиграфії;

4) відсутність віддалених метастатичних вогнищ.

У разі коли функція нирки на стороні ураження була нижчою за 10 мл/хв, проводилася радикальна нефрутеректомія через відсутність клінічних переваг органозберігаючого лікування у таких пацієнтів.

3 метою більш якісного відбору пацієнтів у разі наявності уретерогідронефрозу проводилася нефростомія на ураженій стороні, що дозволяло більш точно оцінити функціональний потенціал нирки. Відтак загалом уретерогідронефроз III-IV стадії було діагностовано у $63 \%$ пацієнтів серед яких $51 \%$ було проведено передопераційну нефростомію. Інші 49\% підлягали оперативному втручанню першим етапом з метою максимально швидкої декомпресії нирки та відновлення іiі функції (у випадках, коли органозбереження було технічно можливим).

Дренування нирки перед початком лікування надавало можливість проведення системної хіміотерапії у хірургічно складних випадках з метою зниження хірургічної складності пухлини та не призводило до пошкодження нирки в процесі лікування

Таблиця 1. Демографічні показники групи пацієнтів з новоутвореннями сечоводів

\begin{tabular}{lc}
\multicolumn{1}{c}{ Показник } & Значення \\
\hline Вік, років & $69,7+9,7$ \\
Стать, ч/ж & $51 / 17$ \\
ECOG-статус & $0(0-1)$ \\
Конкомітантна карцинома сечового міхура, n (\%) & $9(13 \%)$ \\
pT стадія & - \\
T1, n (\%) & $40(59 \%)$ \\
T2, n (\%) & $26(38 \%)$ \\
T3, n (\%) & $2(3 \%)$ \\
T4, n (\%) & $11(16 \%)$ \\
pN стадія & $8(12 \%)$ \\
Grade & $60(88 \%)$ \\
Low, n (\%) & $24(35 \%)$ \\
Нigh, n (\%) & $19(27 \%)$ \\
Лімфоваскулярна інвазія, n (\%) & $43(63 \%)$ \\
Некроз пухлини, n (\%) & \\
Наявність уретерогідронефрозу (III-IV стадії), n (\%) & $6(9 \%)$ \\
Локалізація новоутворення & $8(12 \%)$ \\
Мисково-сечовідний сегмент, n (\%) & $24(35 \%)$ \\
Верхня третина сечоводу, n (\%) & $30(44 \%)$ \\
Середня третина сечоводу, n (\%) & \\
Нижня третина сечоводу, n (\%) & \\
\hline
\end{tabular}




\section{РЕЗУЛЬТАТИ}

Загалом за період дослідження 32 пацієнтам виконано резекцію сечоводу та 36 проведено радикальну нефруретеректомію з резекцією вічка сечоводу. У 9 випадках нефруретеректомія доповнювалася цистектомією у зв'язку з наявністю конкомітантного ураження інвазивною уротеліальною карциномою сечового міхура (рис. 1). Така тактика застосовувалася у разі масивного ураження сечового міхура та неможливості його резекції. У всіх випадках деривацією сечі слугувала однобічна кутанеостомія.

Групи порівняння були співставні за віком, статтю, показником за Шкалою оцінки стану хворого за критеріями Східної об’єднаної онкологічної групи (Eastern Cooperative Oncology Group - ECOG), рівнем гемоглобіну, ступенем диференціювання пухлини $(\mathrm{p}>0,05)$. Група органозберігаючого лікування мала статистично незначущі, проте дещо вищі показники загальної клубочкової фільтрації до оперативного лікування, що, в основному, було пов'язано з наявністю функції нирки на стороні ураження $(67+6,6$ мл/хв порівняно з $61+8,3$ мл/хв; $p=0,056)$. Як видно зданих, пацієнти при обох типах втручання мали загальну середню клубочкову фільтрацію, вищу за 60 мл/хв. Також важливо відмітити, що в групі радикальної нефруретеректоміїпереважали пацієнти з рТ3-4 стадіями ( $=0,034)$, проте рівень ураження регіонарних лімфатичних вузлів був співставним ( 25 vs $28 \%$; $\mathrm{p}=0,067)$.

У табл. 2 представлено порівняння профілю безпеки обох оперативних втручань.

Як видно з табл. 2, статистичної різниці між обома групами не виявлено, тривалість перебування пацієнта в стаціонарі після оперативного втручання була дещо більшою після органозберігаючого лікування, проте це було статистично не значущим. Тривалість оперативного втручання була статистично більшою в групі резекції сечоводу через необхідність реконструкції сечовивідних шляхів, що подовжувало тривалість оперативного втручання та не впливало на рівень післяопераційних ускладнень. Рівні інтраопераційної крововтрати були ідентичними в обох групах. Серед ускладнень переважали Gr 1-2 за Clavien - Dindo, що успішно підлягали консервативному лікуванню. В основному ускладнення були пов'язані із запальними змінами, що потребували пролонгації антибактеріальної терапії. Серед ускладнень Gr 3 спостерігалися рецидиви обструкції верхніх сечовивідних шляхів на стороні ураження в 1-й групі, що коригувались малоінвазивними методиками, тоді як в 2-й групі переважали тривале загоєння післяопераційних ран. Загалом відсоток ускладнень Gr 3 не перевищував $12 \%$ у обох групах. Випадків післяопераційної 30-денної летальності в обох групах відмічено не було.

Таким чином, можна зробити висновок, що консервативні хірургічні втручання при карциномах сечоводу не поступаються в показниках безпеки радикальній нефруретеректомії та, відпо-

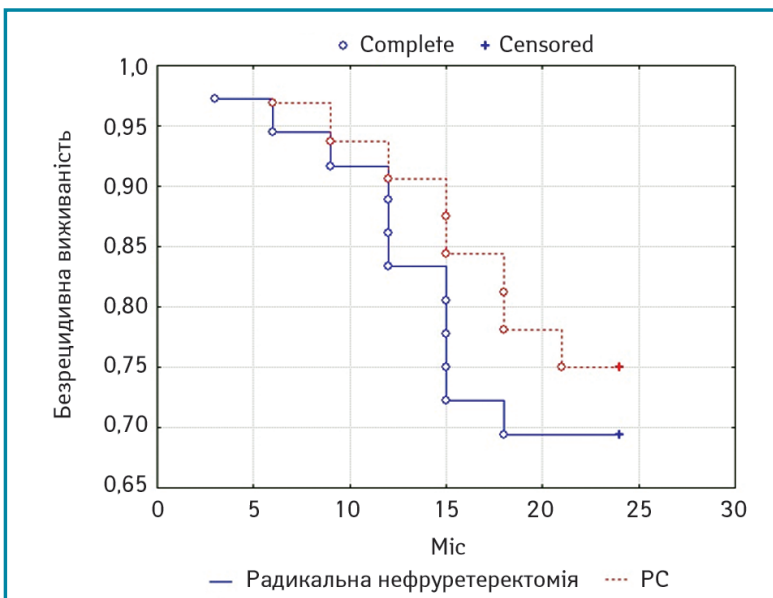

Рис. 1. Кумулятивні криві безрецидивної виживаності пацієнтів після резекцї сечоводу та радикальної нефруретеректомії відно, можуть бути альтернативою органовиносному лікуванню у елективних хворих.

У табл. 3 наведені типи реконструкції сечоводу після проведення резекції його сегменту. Важливо відмітити, що за умови непротяжних уражень сечоводу (не більше 4 см) проводилася пластика власними тканинами сечовидільної системи. У разі більш протяжних уражень чи мультифокальних новоутворень, перевага надавалася кишковій пластиці сечоводу, що дозволяла замістити сегмент будь-якої довжини та фактично нівелювала рецидив пухлини у відділах сечоводу, що знаходилися нижче основного вогнища. У всіх випадках кишкової пластики застосовувалася інтраілеальна пластика та плікація сечоводу за методикою клініки з метою запобігання у віддалений період міхурово-нирковому рефлюксу.

Оцінка функціональних результатів обох груп проводилася за допомогою динамічної реносцинтиграфії перед оперативним втручанням, оцінки роздільної клубочкової фільтрації в добовій сечі (при нефростомії) та формули Кокрофта - Голта відповідно до показників сироваткового креатиніну. Перед оперативним втручанням усі пацієнти проходили оцінку роздільної клубочкової фільтрації, що фактично слугувала маркером відбору пацієнтів для проведення органозберігаючого втручання. Оцінка функції нирок виконувалась через 3 міс після хірургічного лікування. У післяопераційний період у хворих, яким виконували радикальну нефруретеректомію, оцінювали лише загальну клубочкову фільтрацію за рівнем сироваткового креатиніну, оскільки ці дані відображали функцію єдиної нирки. Пацієнти після резекції сечоводу через 3 міс повторно проходили динамічну реносцинтиграфію з метою оцінки роздільної клубочкової фільтрації.

Дані клубочкової фільтрації обохгруп до та після оперативного втручання представлені в табл. 4.

Як видно з табл. 4, при статистично співставних показниках загальної клубочкової фільтраціїдо оперативного втручання $(\mathrm{p}=0,09)$ в післяопераційний період отримано кращі показники в групі резекції сечоводу ( $\mathrm{p}=0,002)$. Варто відмітити, що такого показника було досягнуто найбільш вірогідно за рахунок збереженої нирки на стороні ураження $(19,3+4,9$ мл/хв). Відтак органозберігаюче

Таблиця 2. Порівняння профілю безпеки обох оперативних втручань

\begin{tabular}{|c|c|c|c|}
\hline Ускладнення & $\begin{array}{c}\text { Резекція } \\
\text { сечово- } \\
\text { ду, } \\
\text { n=32 }\end{array}$ & $\begin{array}{c}\text { Радикальна } \\
\text { нефрурете- } \\
\text { ректомія, } \\
\text { n=36 }\end{array}$ & $\boldsymbol{P}$ \\
\hline Gr 1-2 & 18 & 12 & \\
\hline Gr 3-4 & 4 & 3 & 0,07 \\
\hline Інтраопераційна крововтрата, мл & $246+79$ & $202+69$ & 0,23 \\
\hline Тривалість оперативного втручання, хв & $179+22$ & $142+32$ & 0,16 \\
\hline Тривалість перебування в стаціонарі, дні & $6,6+1,1$ & $5,3+0,9$ & 0,68 \\
\hline
\end{tabular}

Таблиця 3. Типи реконструкції верхніх сечовивідних шляхів після резекції сечоводу

\begin{tabular}{lc}
\hline \multicolumn{1}{c}{ Типи реконструкції } & Резекція сечоводу(n=32) \\
\hline Уретероцистонеостомія & 11 \\
Анастом03 кінець-в-кінець & 7 \\
Пластика МСС за Андерсеном - Хайн- & 6 \\
цом & \\
Кишкова пластика сечоводу & 8 \\
\hline
\end{tabular}

Таблиця 4. Показники функції нирок досліджуваних груп до та після оперативного лікування

\begin{tabular}{|c|c|c|}
\hline Показник & $\begin{array}{c}\text { Резекція сечо- } \\
\text { воду }\end{array}$ & $\begin{array}{c}\text { Радикальна не- } \\
\text { фруретеректомія }\end{array}$ \\
\hline \multicolumn{3}{|l|}{ До оперативного втручання } \\
\hline $\begin{array}{l}\text { Загальна клубочкова фільтра- } \\
\text { ція, мл/хв }\end{array}$ & $67+6,6$ & $61+8,3$ \\
\hline \multicolumn{2}{|l|}{ нирки, мл/хв } & $5,1+2,4$ \\
\hline Після оперативного втручання & & \\
\hline $\begin{array}{l}\text { Загальна клубочкова фільтра- } \\
\text { ція, мл/хв }\end{array}$ & $68+7,1$ & $54+9,2$ \\
\hline $\begin{array}{l}\text { Клубочкова фільтрація ураженої } \\
\text { нирки, мл/хв }\end{array}$ & $19,3+4,9$ & - \\
\hline
\end{tabular}


лікування дозволяло утримати загальну клубочкову фільтрацію вище 60 мл/хв, що принципово впливало на вірогідність проведення ефективної системної терапії в післяопераційний період. Важливим моментом $є$ також позитивний вплив такого рівня функції нирок на зниження вірогідності настання кардіоваскулярних подій.

Нирковозберігаючий підхід улікуванні карцином сечоводупідвищував вірогідність проведення комбінованого лікування за рахунок утримання ниркової функції на передопераційному рівні.

В подальшому нами було оцінено 2-річну безрецидивну та загальну виживаність. Період оцінки було обрано з метою включення максимальної кількості пацієнтів для якісного аналізу.

Криві виживаності представлені на рис. 1. та 2.

Як видно з рис. 1, групи були ідентичними за кількістю рецидивів у сечовому тракті. Після радикальної нефруретеректомії у $31 \%$ випадків спостерігалися імплантаційні ураження сечового міхура, тоді як після резекції сечоводу показник відповідав 25\% (рецидиви в ураженому сечоводі та сечовому міхурі). Таким чином, органозберігаюче лікування статистично достовірно не підвищувало ризик рецидиву в сечовивідній системі (log-rank test; $p=0,55)$. При аналізі показників загальної 2-річної виживаності також не було відмічено статистичної різниці між хірургічними групами (log-rank test; $p=0,62$ ).

\section{ОБГОВОРЕННЯ}

Згіно з рекомендаціями Європейської асоціації урологів (European Association of Urology - EAU) та Національної загальної онкологічної мережі (National Comprehensive Cancer Network - NCCN), резекція сегменту верхніх сечовивідних шляхів при карциномі верхніх сечовивідних шляхів високого ризику можлива лише за умови наявності єдиної функціонуючої ураженої нирки, білатеральних пухлин або вираженої супутньої патології, котра може ускладнитися після видалення нирки [6]. Проте це $є$ чи не єдиною опцією збереження можливості проведення ефективного комбінованого лікування. Виключенням з правил $€$ нижня третина сечоводу, де резекція з наступною реконструкцією шляхом уретероцистонеостомії $€$ клінічно та функціонально виправданою. Ця локалізація є хірургічно найбільш простою та забезпечує оптимальний онкологічний контроль [9-12]. Таким чином, дослідження Jeldres i співавторів та Colin і співавторів показали, що парціальна уретеректомія (сегментарна уретеректомія) при Т1-2 уротеліальних карциномах, не поступається в онкологічних результатах радикальній нефруретеректомії, забезпечуючи 5-річну канцер-специфічну виживаність на рівні 86\%. 3 іншого боку, у ході досліджень було показано, що це стосувалося лише локалізованих пухлин, тоді як при ураженнях Т3-Т4 - побудова кривих виживаності не мала сенсу через значно гірші онкологічні результати в групі органозбереження (p>0,2) [7-8]. Втім ми розуміємо, виходячи зданих, які вже були представлені, що агресивність

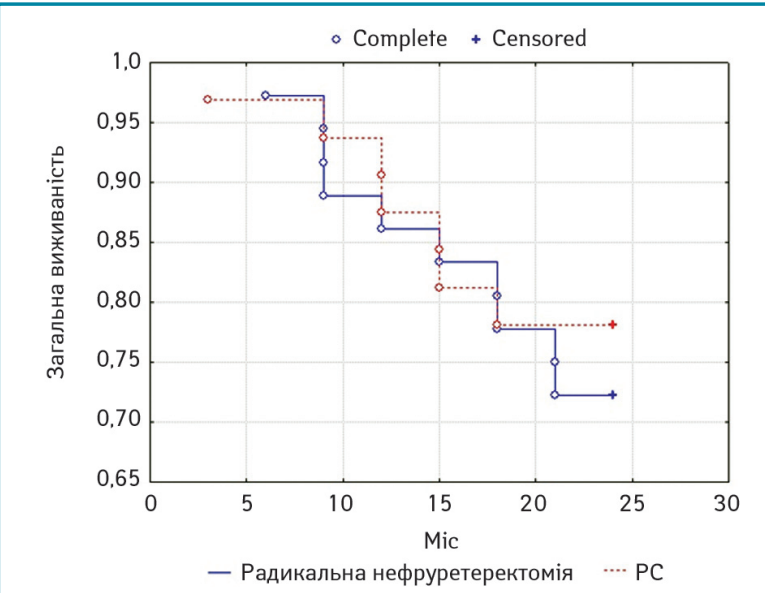

Рис. 2. Кумулятивні криві загальної виживаності пацієнтів після резекцї сечоводу та радикальної нефруретеректомії місцево-поширених уротеліальних карцином є значно вищою, ніж локалізованих та, відповідно, такі пацієнти потребують більш детального відбору. Ефективний відбір теоретично можливо провести двома шляхами: шляхом визначення потенційної агресивності пухлини внаслідок оцінки біомаркерної активності або проведення передопераційної хіміотерапії, що дасть можливість оцінити чутливість новоутворення до системного лікування.

Метою проведеного дослідження був розгляд ролі консервативної хірургії при лікуванні новоутворень сечоводу. Резекція сечоводу характеризується задовільним профілем безпеки, що не відрізняється від радикальної нефруретеректомії. Рівень післяопераційних ускладнень, що потребували медикаментозної чи малоінвазивної корекції, не перевищував $12 \%$.

При статистично співставних показниках загальної клубочкової фільтрації до оперативного втручання $(p=0,09)$ в післяопераційний період отримано кращі показники в групі резекції сечоводу $(\mathrm{p}=0,002)$. Варто відмітити, що такого показника було досягнуто найбільш вірогідно за рахунок збереженої нирки на боці ураження (19,3+4,9 мл/хв). Відтак органозберігаюче лікування дозволяло утримати рівень загальної клубочкової фільтрації вище 60 мл/хв, що принципово впливало на вірогідність проведення ефективної системної терапії в післяопераційний період. Важливим моментом є також позитивний вплив такого рівня функції нирок на зниження вірогідності настання кардіоваскулярних подій.

Нирковозберігаючий підхід улікуванні карцином сечоводу підвищував вірогідність проведення комбінованого лікування за рахунок утримання ниркової функції на передопераційному рівні.

Період оцінки безрецидивної та загальної виживаності через 2 роки було обрано з метою включення максимальної кількості пацієнтів для якісного аналізу. Групи мали співставні показники безрецидивної та загальної виживаності, що, безперечно, вказує на доцільність проведення органозберігаючого втручання у зв'язку з безумовною функціональною перевагою такого методу.

\section{ВИСНОВКИ}

Резекція сечоводу при уротеліальних карциномах верхніх сечовивідних шляхів високого ризику є безпечним оперативним втручанням з точки зору периопераційних ускладнень в порівнянні з радикальною нефруретеректомією. Органозберігаюче лікування у цих пацієнтів достовірно призводить до збереження функції нирки на стороні ураження та рівня загальної клубочкової фільтрації вище 60 мл/хв. Рівень локального контролю в сечовій системі є співставним при обох хірургічних підходах, що не погіршує остаточний онкологічний результат. Збереження функції нирки та імплементація комбінованого лікування спрямовані на покращення онкологічних результатів лікування та показників виживаності пацієнтів з карциномі верхніх сечовивідних шляхів високого ризику.

\section{СПИСОК ВИКОРИСТАНОÏ ЛІТЕРАТУРИ}

1. Oosterlinck, W., Solsona, E., van der Meijden, A. P. M, Sylvester, R., Böhle, A., Rintala, E., \& Lobel, B. (2004) EAU guidelines on diagnosis and treatment of upper urinary tract transitional cell carcinoma. Eur Urol, 46, 147-15.

2. Seisen, T., Colin, P. \& Rouprêt, M. (2015) Risk-adapted strategy for the kidney-sparing management of upper tracttumours. NatRevUrol, 12(3), 155-66. doi: 10.1038/nrurol.2015.24.

3. Lughezzani, G., Jeldres, C., Isbarn, H., Sun, M., Shariat, S. F., Ahmed Alasker... Karakiewicz, P. I. Nephroureterectomy and segmental ureterectomy in the treatment of invasive upper tract urothelial carcinoma: a population-based study of 2299 patients. Eur J Cancer, 45, 3291. https://www.ncbi.nlm.nih.gov/pubmed/19615885.

4. Rink, M., Sjoberg, D., Comploj, E., Margulis, V., Xylinas, E., Richard K.... Shariat, S. F. (2012) Risk of cancer-specific mortality following recurrence after radical nephroureterectomy. Ann Surg Oncol, 19(13): 4337-4344. doi: 10.1245/s10434-012-2499-8.

5. Thompson, R. H., Krambeck, A. E., Lohse, C. M., Elliott, D. S., Patterson, D. E, Blute, M. L(2008) Endoscopic management of upper tract transitional cell carcinoma in patients with normal contralateral kidneys. Urology, 71, 713-717.

6. Jeldres, C., Sun, M., Isbarn, H., Lughezzani G., Budäus, L., Alasker. A. \& Karakiewicz, P. I. (2010) A population-based assessment of perioperative mortality after nephroureterectomy for upper-tract urothelial carcinoma. Urology, 75: 315. https://www.ncbi.nlm.nih.gov/pubmed/19963237.

7. Jeldres, C., Lughezzani, G., Sun. M., Isbarn H., ShariatS. F, Budaus L., \& Karakiewicz P. I (2010) Segmental ureterectomy can safely be performed in patients with transitional cell carcinoma of the ureter. J Urol, 183, 1324. https://www.ncbi.nlm.nih.gov/pubmed/20171666.

8. Colin, P., Ouzzane, A., Pignot, G., Ravier, E., Crouzet S., Ariane M. M.,\& Rouprêt, M. (2012) Comparison of oncological outcomes after segmental ureterectomy or radical nephroureterectomy in urothelial carcinomas of the upper urinary tract: results from a large French multicentre study. BJU/nt, 110, 1134 https://mun.ncbi.nlm nih gov/pubmed/22394612.

9. Seisen, T., Peyronnet, B., Dominguez-Escrig, J. L., Bruins, H. M., Yuan, C. Y., Babjuk M., \& Rouprêt, M. Oncologic Outcomes of Kidney-sparing Surgery Versus 
RadicalNephroureterectomy for Upper Tract Urothelial Carcinoma: A Systematic Review by the EAU Non- muscle Invasive Bladder Cancer Guidelines Panel. Eur Urol, 70: 1052. https://www.ncbi.nlm.nih.gov/pubmed/27477528.

10. Seisen, T., Colin, P., Rouprêt, M. (2015) Risk-adapted strategy for the kidney-sparing management of upper tract tumours. Nat Rev Urol, 12, 155 https://www.ncbi.nlm.nih.gov/pubmed/25708579.

11. Xylinas, E., Rink. M., Margulis, V., Clozel, T., Lee R. K., Comploj, E.,\& Shariat, S. F. (2013) Impact of renal function on eligibility for chemotherapy and survival in patients who have undergone radical nephro-ureterectomy. BJU Int, 112(4), 453-61. doi: 10.1111/j.1464-410X.2012.11649.x.

12. Xylinas, E., Roupret, M., Shariat, S. F. (2013) Segmental ureterectomy for upper tract urothelial carcinoma: two procedures with different indications. Urol Oncol, 31: 1841-3.

\section{Клиническая эффективность резекции \\ мочеточника при инвазивных карциномах верхних мочевыводящих путей}

М.В. Пикуль, Э.А. Стаховский, А.А. Войленко, О.Е. Стаховский, Ю. Витрук, О.А. Кононенко, С.Л. Семко, Б.А. Гречко, Д.А. Кошель, А.А. Каркич

\section{Национальный институт рака, Киев}

Вступление. Учитывая особенности течения карцином верхних мочевыводящих путей и частый дебют заболевания с имеющейся почечной недостаточностью, сохранение уровня клубочковой фильтрации является крайне важным. Риск рецидива заболевания в болышей степени зависит от агрессивности самой опухоли, а не от выбранного типа вмешательства. Соответственно, пациенты с более агрессивными опухолями чаще будут нуждаться в следующей системной терапии, проведение которой часто лимитировано уровнем клубочковой фильтрации после радикальной нефруретерэктомии. Материалы и методы. Учитывая цели и задачи научной работы, пациенты были разделены на 2 группы: с карциномой мочеточника, подлежащие органосохраняющему лечению (основная группа), и радикальной нефруретерэктомии (контрольная группа). Первичными целями такого анализа считались оценка профиля безопасности обоих видов хирургических подходов, включающих определение продолжительности оперативного вмешательства, интраоперационную кровопотерю, уровень послеоперационных осложнений по оценочной системой Clavien - Dindo, продолжительность послеоперационного стационарного лечения. Вторичными целями исследования были оценка отдаленных функциональных результатов (общая клубочковая фильтрация, уровень сывороточного креатинина через 3 мес после оперативного вмешательства) и онкологических результатов (уровни безрецидивной, канцер-специфической, общей выживаемости, а также выживаемости без прогрессирования) обеих групп. Pезультаты. При статистически сопоставимых показателях общей клубочковой фильтрации до оперативного вмешательства $(\mathrm{p}=0,09)$ в послеоперационный период получены лучшие показатели в группе резекции мочеточника $(\mathrm{p}=0,002)$. Стоит отметить, что такой показатель был достигнут, наиболее вероятно, за счет сохраненной почки на стороне поражения (19,3+4,9 мл/мин). Поэтому органосохраняющее лечение позволяло удержать общую клубочковую фильтрацию выше 60 мл/мин, что принципиально повлияло на вероятность проведения эффективной системной терапии в послеоперационный период. Важным моментом является также положительное влияние такого уровня функции почек на снижение вероятности наступления кардиоваскулярных событий. Группы были идентичными по количеству рецидивов в мочевом тракте. После радикальной нефроэктомии в $31 \%$ случаев отмечали имплантационное поражение мочевого пузыря, тогда как после резекции мочеточника показатель соответствовал $25 \%$ (рецидивы в пораженном мочеточнике и мочевом пузыре). Таким образом, органосохраняющее лечение статистически достоверно не повышало риск рецидива в мочевыводящей системе (log-rank test; p=0,55). При анализе показателей общей двухлетней выживаемости также не было отмечено статистической разницы между хирургическими группами (log-rank test; p=0,62). Выводы. Резекция мочеточника при уротелиальных карциномах верхних мочевыводящих путей высокого риска является безопасным оперативным вмешательством с точки зрения периоперационных осложнений по сравнению с радикальной нефрэктомией. Органосохраняющее лечение уэтих пациентов достоверно приводит к сохранению функции почки на стороне поражения и уровня общей клубочковой фильтрации выше 60 мл/мин. Уровень локального контроля в мочевой системе сопоставим при обоих хирургических подходах, не ухудшает конечный онкологический результат.

Ключевые слова: уротелиальный рак; карцинома верхних мочевыводящих путей; радикальная нефруретерэктомия; малоинвазивные органосохраняющие оперативные вмешательства; клубочковая фильтрация; карцинома мочеточника; химиотерапия на основе платины.

Clinical efficacy of partial ureterectomy in patients with invasive carcinomas of the upper urinary tract

M.Pikul, E. Stakhovsky, O. Voylenko, O. Stakhovsky, Iu. Vitruk,

O. Kononenko, S. Semko, B. Hrechko, D. Koshel, O. Karkych National Cancer Institute of Ukraine

Abstract. Introduction. Upper urinary tract carcinoma features and the frequent onset of the disease with existing chronic kidney disease create a paradigm for preservation of the level of glomerular filtration which could be extremely important. The risk of recurrence depends more on ttumor agressiveness, rather than on the chosen type of surgical intervention. Accordingly, patients with more aggressive tumors will be more likely to require systemic therapy, which is often limited by the level of glomerular filtration after radical nephrureterectomy.Materials and methods. Taking to account the purpose and objectives of scientific work, patients were divided into 2 groups: patients with carcinoma of urerter undergoing organ-sparing treatment (main group) and radical nephroureterectomy (control group). The primary objectives of this analysis were to assess the safety profile of both types of surgical approaches, which included determining the duration of surgery, intraoperative hemorrhage, the level of postoperative complications according to the evaluation system - Clavien-Dindo, the duration of postoperative inpatient treatment. The secondary objectives of the study were to assess long-term functional outcomes (total glomerular filtration rate, serum creatinine levels after 3 months from time of surgery) and oncological outcomes (recurrence-free, progressive, cancer-specific, and overall survival levels) of both groups. Results. With statistically comparable indicators of total glomerular filtration before surgery $(p=0.09)$, results obtained after surgery were better in partial ureterectomy group $(p=0.002)$. It is important to note that this fwas most likely due to the preserved kidney on the affected side $(19.3+$ $4.9 \mathrm{ml} / \mathrm{min})$. Therefore, organ-preserving treatment allowed to keep the total glomerular filtration above $60 \mathrm{ml} / \mathrm{min}$, which fundamentally affected the likelihood of effective systemic therapy in the postoperative period. Another important point is the positive effect of this level of renal function on reducing the likelihood of cardiovascular events. (groups were identical by the number of recurrences in the urinary tract). Thus, organ-sparing treatment did not statistically significantly increase the risk of recurrence in the urinary system $(\log$-rank test; $p=0.55)$. The analysis of overall two-year survival also showed no statistical difference between surgical groups (log-rank test; $\mathrm{p}=0.62$ ). Conclusions. Partial ureterectomy in high-risk urothelial carcinomas of the upper urinary tract is a safe surgical intervention in terms of perioperative complications compared with RNUE. Organ-sparing treatment in these patients reliably leads to the preservation of renal function on the affected side and saving the level of total glomerular filtration above $60 \mathrm{ml} / \mathrm{min}$. The level of local control in the urinary system is comparable in both surgical approaches, which does not worsen the final cancer outcome.

Key words: Urothelial cancer; upper urinary tract cancer; radical nephroureterectomy; minimally invasive organ-sparing surgery; glomerulal filtration; ureteral cancer; platinum based chemotherapy.

Aдреса:

Пікуль Максим Валентинович

03022 Київ, вул. Ломоносова, 33/43

Національний інститут раку

E-mail: urogenetics@gmail.com 